3

4

5

\title{
EVALUATION OF NEMATICIDES FOR SOUTHERN ROOT-KNOT NEMATODE MANAGEMENT IN LIMA BEAN
}

Author List: Jake G. Jones ${ }^{\mathrm{a}^{*}}$, Nathan M. Kleczewski ${ }^{\mathrm{a}}$, Johan Desaeger ${ }^{\mathrm{b}}$, Susan L. F. Meyer ${ }^{\mathrm{c}}$, Gordon C. Johnson ${ }^{\mathrm{a}}$

${ }^{a}$ Dept. Plant and Soil Sciences, University of Delaware, Carvel Research and Education Center, 16483 County Seat Hwy, Georgetown, DE 19947 USA

${ }^{\mathrm{b}}$ Dept. of Entomology and Nematology, University of Florida, Gulf Coast Research and Education Center, 14625 CR 672, Wimauma, FL 33598 USA

${ }^{\mathrm{c}}$ Mycology and Nematology Genetic Diversity and Biology Laboratory, USDA ARS, Bldg. 010A, Rm. 112, BARC-West, Beltsville, MD 20705 USA

*Corresponding author: email: jgjones@umd.edu, Cell Phone: 302-448-0624, Present Address: 27664 Nanticoke Rd, Salisbury, MD 21801 USA

Keywords: Meloidogyne incognita, fluensulfone, fluopyram, spirotetramat, ethoprophos, Phaseolus lunatus.

\begin{abstract}
Southern root-knot nematodes (Meloidogyne incognita; RKN) significantly reduce lima bean (Phaseolus lunatus) yields. Chemical control options for RKN are limited. We evaluated the efficacy of new nematicidal products on RKN in lima bean experiments conducted in greenhouse (GH) and microplot (MP) settings. Treatments included fluensulfone at low and high labeled rates, fluopyram, spirotetramat, fluopyram+spirotetramat, oxamyl, ethoprophos, and an untreated, RKN-infested control. GH treatments were arranged in a factorial design, with application of nematode eggs $\left(0,6,000\right.$, or 30,000 eggs $\left.\operatorname{pot}^{-1}\right)$ crossed with nematicide treatment. MP treatments were arranged in a randomized complete block design and all plots were infested with RKN-infested tomato root tissue and soil grown in the greenhouse. Root galling, RKN egg
\end{abstract}


and juvenile densities, and aboveground plant dry masses were determined and analyzed using

27 Mixed Model ANOVA. In the GH trials, fluensulfone at both rates provided the greatest reduction in RKN galling compared to the untreated control, whereas spirotetramat treatments were not significantly different from the untreated control. In the MP 2 trial, all treatments except spirotetramat significantly reduced RKN populations and had significantly greater yields relative to the untreated control. Oxamyl, ethoprophos, and fluensulfone $(1.64 \mathrm{~L}$ ai/ha and $2.34 \mathrm{~L}$ ai/ha) treatments had the highest yields in the microplot study. Based on these results, the two new nematicides, fluensulfone and fluopyram, show good potential for managing RKN in lima beans.

Root knot nematodes (Meloidogyne spp.) have a host range of over 1,700 plant species and are responsible for approximately 5\% of crop losses worldwide (Barker 1998; McCarter 2008). Meloidogyne spp. are considered the most damaging plant-parasitic nematodes in the world, and include four major species: $M$. arenaria, $M$. hapla, M. incognita, and $M$. javanica (Jones et al. 2013, Moens et al. 2009). Southern root-knot nematode (RKN), M. incognita

41 (Kofoid and White 1919), is commonly found in soils in the mid-Atlantic region and can cause 42 extensive damage to crops via the formation of giant cells (galls), which impede nutrient and 43 water uptake in the plant and consume plant nutrients, resulting in reduced plant growth and 44 productivity, or even plant death (Karssen et al. 2013, Barker 1998).

The mid-Atlantic region is predisposed to successful RKN infections, as the predominate soil types have a large sand component, thereby facilitating RKN movement in the soil and

47 infection of plant roots (Wallace 1968, UDSA NRCS). RKN are capable of severely damaging 48 many vegetable crops, including lima beans (Phaseolus lunatus). 
Delaware has more hectares of lima beans than any other state in the U.S., with a ten-year average of 5,261 hectares planted and harvested annually. Lima bean accounts for $43 \%$ of total vegetable processing hectares in Delaware on average and $27 \%$ of the total value produced from processing vegetables, thereby contributing approximately $\$ 5.65$ million to state growers annually (NASS and DDA 2014). Consequently, lima bean yields must be protected in order to ensure the crop's continued production in Delaware and the mid-Atlantic region.

RKN on lima beans is of increasing importance and more effective management practices are needed (PMSP 2003). Chemical controls were for decades an effective stand-alone tool in the control of RKN (Moens et al. 2009). Effective fumigants such as 1,2-dibromo-3-chloropropane (DBCP), ethylene dibromide (EDB), and methyl bromide, as well as non-fumigants including fenamiphos, carbofuran, and aldicarb, provided excellent control, but their environmental impacts, issues with human safety, and other concerns led to their discontinuation (Johnson and Feldmesser 1987, Abdel-Rahman et al. 2008, Aspelin and Grube 1999, Giannakou et al. 2002, UNEP 1992, EPA 2008, EPA 2009, EPA 2012). Most non-fumigant nematicides fall into one of two classes: carbamates or organophosphates. These chemicals inhibit acetylcholinesterase, which leads to nematode paralysis (Chitwood 2001, IRAC 2015). Both classes of chemicals are considered highly toxic to humans and the environment, with the majority lacking specificity in their toxicity, leading to heavy regulation and scrutiny (Gupta 2011). Phase-outs of synthetic nematicides have left a void in RKN control as the development of safer, non-fumigant chemical control options has not kept pace with the loss of the older nematicides (Nyczepir and Thomas 2009).

As a consequence of the deregistration of synthetic nematicides, and the high cost of using them, the main nematode control measures that growers utilize in the region are cultural 
72 controls, including crop rotation, avoidance of infested fields and biofumigation with rapeseed.

73 The resulting RKN reduction from crop rotation and rapeseed is often transient and inconsistent

74 (Everts et al. 2006). However, several non-carbamate/organophosphate active ingredients have

75 recently received EPA registration as nematicides. These include spirotetramat (2010),

76 fluensulfone (2014) and fluopyram (2015) (Table 1).

77 Spirotetramat is a systemic insecticide labeled for use in certain tree, tropical fruits, vine

78 and vegetable crops, including lima beans, with up to two foliar applications per growing season.

79 There is evidence that spirotetramat may suppress plant-parasitic nematode populations after

80 foliar applications (McKenry et al. 2009, McKenry et al. 2010). Timing appears to be critical for

81 the effectiveness. Spirotetramat does not prevent the nematodes from invading roots, because the

82 nematodes must ingest the translocated chemical for efficacy. Therefore, galls will still appear,

83 but egg production, and therefore overall RKN populations, may be reduced (Perry et al. 2013).

84 Fluensulfone is labeled for use in cucumbers, melons, squash, tomatoes, okra, eggplant, and

85 peppers, and is marketed as a contact nematicide, but also has some systemic activity (Oka et al.

86 2011, Kearn et al. 2014, Oka et al. 2009). The efficacy of fluensulfone has been studied in recent

87 years on vegetables such as cucurbits, carrots, and tomatoes, but not on lima bean crops (Oka et

88 al. 2011, Morris et al. 2015, Morris et al. 2016). In a study by Oka et al. (2009) fluensulfone

89 application reduced the fresh weights of tomato plants, albeit inconsistently, indicating a need for

90 more research on its phytotoxicity among a variety of crops. Fluopyram is labeled as a

91 nematicide seed treatment in soybean and for liquid application on potatoes, cotton, and peanut.

92 In addition, fluopyram is an effective fungicide and has been studied for its efficacy against RKN

93 as well as its use in controlling Sudden Death Syndrome of soybean (Faske and Hurd 2015, 
94 Kandel et al. 2016). Fluopyram has been shown to cause some phytotoxicity in soybeans but its

95 effects on lima beans and RKN are unknown (Kandel et al. 2016).

The objective of this research was to compare the efficacy of these new nematicides to

97 each other and to other select nematicides for suppression of RKN in lima bean. To accomplish this, we evaluated the nematicides for RKN control in greenhouse and microplot experiments.

\section{Materials and Methods}

100

101

102

103

104

105

106

107

108

109

110

111

112

113

114

115

116

\subsection{Greenhouse Experiments}

Two greenhouse trials (GH 1, GH 2) were conducted at the Fischer Greenhouses (531 South College Ave. Newark, DE) at the University of Delaware's main campus from November 6, 2015 through December 15, 2015 and from March 22, 2016 through April 28, 2016, respectively. A spatially balanced factorial design was used, consisting of three levels of RKN inoculum $\left(0,3,000\right.$, and 6,000 eggs pot $\left.^{-1}\right)$, and egg inoculum levels were crossed with each of seven chemical treatments and an untreated control (Kayani et al. 2016) (Table 1). Each experimental combination was replicated six times and the entire experiment was replicated twice (GH 1, GH 2), for a total of 288 units in the combined trials (144 experimental units per trial). Experimental units were $10.2 \mathrm{~cm}$ square plastic pots filled $3 / 4$ full with screened, autoclaved Pepperbox loamy sand (70 to $80 \%$ sand), with organic matter (OM) of 1.0 and $1.1 \%$, and $\mathrm{pH}$ of 5.2 and 4.8, respectively, for GH 1 and GH 2 (USDA NRCS). The soil was acquired from the University of Delaware Carvel Research and Education Center in Georgetown, Delaware. Two untreated ' 242 ' Fordhook bush lima bean seeds were planted in each pot, and thinned to one seedling per pot 10 and 12 days after planting (DAP) for GH 1 and GH 2, respectively. Pots were arranged on a bench containing heat mats set at $27^{\circ} \mathrm{C}$. Plants received supplemental lighting provided by high pressure sodium lamps set to maintain 12 hours of daylight when the outside 
117 light dropped below 400 Lux. The average temperature in $\mathrm{GH} 1$ was $22.8^{\circ} \mathrm{C}$, with a low of $11818.8^{\circ} \mathrm{C}$ and a high of $27.4^{\circ} \mathrm{C}$, while the average temperature in $\mathrm{GH} 2$ was $23.2^{\circ} \mathrm{C}$, with a low of $119 \quad 18.8^{\circ} \mathrm{C}$ and high of $32.3^{\circ} \mathrm{C}$. Pots were watered as needed. For both greenhouse trials, RKN populations were increased on the susceptible tomato 121 host Lycopersicum esculentum cv. Rutgers, grown in the greenhouse for 42 days (GH 1) and 60 122 days (GH 2) in a mixture of sand and field soil. RKN eggs were extracted with $0.5 \% \mathrm{NaOCl}$ 123 from infected roots and were adjusted with the aid of a hemocytometer to add concentrations of 1246,000 and 30,000 eggs per pot (low and high rates). Next, $3 \mathrm{~mL}(\mathrm{GH} 1)$ or $12 \mathrm{~mL}(\mathrm{GH} 2)$ of the 125 respective egg suspension was added into three holes, $4 \mathrm{~cm}$ deep, placed at equal distance around 126 the circumference of each pot (Kayani et al. 2016). Fluensulfone treatments were applied the same day as RKN egg inoculation, 7 days prior 128 to lima bean planting, as recommended by the manufacturer. Fluopyram, oxamyl, and 129 ethoprophos were all applied pre-plant on the day of planting. Spirotetramat was applied to 130 appropriate treatments after growth of foliage was sufficient to apply the foliar spray on 19 (GH 131 1) and 16 DAP (GH 2). See Table 1 for a complete list of chemical treatments, modes-of-action, 132 rates, and application methods.

On 32 (GH 1) and 30 DAP (GH 2) the experiments were harvested. Shoots were 134 separated from the roots at the soil line and placed in paper bags before drying until constant dry 135 mass at $60^{\circ} \mathrm{C}$. Roots were rinsed in running tap water to remove soil and debris, and then stored 136 in sealed plastic bags at $4.5^{\circ} \mathrm{C}$ until egg masses were counted. RKN egg masses were stained red 137 with $15 \mathrm{mg}$ phloxine $\mathrm{B} / \mathrm{L}$ of water and enumerated under a dissecting microscope (Dickson and 138 Struble 1965). After counting, roots were placed in paper bags and dried as described above, to 139 allow for calculations of egg masses per gram root dry weight. Dry weights (g) were recorded for 
140 the shoots and roots of each chemical treatment. The dry masses of the shoots and roots were

141 combined and used to calculate the carbon allocation and total biomass patterns for each

142 chemical treatment.

143 All data were tested for normality using the Shapiro-Wilk Goodness of Fit test before

144 analysis. Transformations for normality in both trials were performed on percent root weight data

145 (Log transformed) and egg masses per root dry weight (g) (Log+1 transformed). A random

146 effects mixed model was used with block as a random effect with treatment, and egg level

147 combinations as fixed effects. Pots not receiving eggs (controls) were not included in

148 assessments of treatments on RKN. However, controls were analyzed separately to test the

149 effects of chemical treatments on overall plant growth and productivity in the absence of RKN.

150 Means were separated following significant ANOVA using Student's Protected LSD ( $\alpha=0.05)$.

151 Preliminary analysis indicated a significant effect of experimental trial on data $(\mathrm{P}<0.0001)$ and

152 studies were therefore analyzed separately (SAS Institute, Cary, N.C.).

153 2.2. Microplot Experiments

154 Microplot (MP) studies were conducted at the University of Delaware's Elbert N. and

155 Ann V. Carvel Research and Education Center (16483 County Seat Hwy. Georgetown, DE

156 19947). The soil type in the microplot trials was a Pepperbox loamy sand (70 to $80 \%$ sand), with

$157 \quad 1.0$ and $0.8 \% \mathrm{OM}$, and $\mathrm{pH}$ of 4.2 and 4.8, respectively, for Microplot 1 trial (MP 1) and

158 Microplot 2 trial (MP 2) (USDA NRCS). In 2014, a set of semi-permanent, 61 x $61 \mathrm{~cm}$ (diameter

$159 \mathrm{x}$ height) circular microplots made from High Density Polyethylene (HDPE) resin tree nursery

160 pots with the bottoms removed were installed to a depth of $51 \mathrm{~cm}$ for MP 1 . In 2015, a set of

161 permanent, $61 \times 122 \mathrm{~cm}$ circular microplots made from corrugated Polyethylene tile pipe were

162 installed to a depth of $92 \mathrm{~cm}$ for MP 2. Microplots were spaced apart with aboveground lips to 
163 avoid cross-contamination during both experiments. Experiments were arranged in random

164 complete block designs, with 5 blocks and 3 and 7 chemical treatments plus untreated controls in

1652014 and 2015, respectively (Table 1). Weeds were controlled mechanically and by hand for

166 both trials. Microplots were fertilized with the recommended rates of $62 \mathrm{~kg} / \mathrm{ha}$ nitrogen, $67 \mathrm{~kg} / \mathrm{ha}$

167 phosphorus, and $112 \mathrm{~kg} / \mathrm{ha}$ potassium. The microplots were irrigated by hand throughout the

168 experiments to add the equivalent of $2.5 \mathrm{~cm}$ of rainfall per week.

169

RKN populations were increased on the susceptible tomato host Lycopersicum

170 esculentum cv. Rutgers in the greenhouse. On July 9, 2014, each microplot in MP 1 was

171 inoculated with a $2.72 \mathrm{~kg}$ mixture of infested tomato roots and soil. On July 22, 2015, each

172 microplot in MP 2 was inoculated with a $4.80 \mathrm{~kg}$ mixture of infested tomato roots and soil,

173 equivalent to 120,000 eggs and 3,450 second stage RKN juveniles (J2) per microplot (no

174 population counts were taken in MP 1). The inoculum was chopped and mixed before

175 application to each microplot and was immediately incorporated into the upper $30 \mathrm{~cm}$ of soil.

176 Nematicide treatments included: 1) fluopyram (0.22 L ai/ha [MP 1, MP 2]), 2)

177 ethoprophos (4.10 kg ai/ha [MP 1, MP 2]), 3) fluensulfone high rate (2.34 L ai/ha [MP 1, MP 2]),

178 4) fluensulfone low rate (1.64 L ai/ha [MP 2]), 5) oxamyl (2.25 L ai/ha [MP 2]), 6) spirotetramat

$179(2 \mathrm{x})(0.37 \mathrm{~L}$ ai/ha each application [MP 2]), 7) a combination of fluopyram followed by

180 spirotetramat (0.22 L ai/ha and 0.37 L ai/ha, respectively [MP 2]), and 8) an untreated control

181 [MP 1, MP 2] (Table 1). Chemical treatments were applied on July 15, 2014 for MP 1 and July

182 23, 2015 for MP 2. In MP 2, spirotetramat was applied at 20 DAP to the spirotetramat (2x) and

183 fluopyram + spirotetramat treatment plots, and again 27 DAP for the second treatment in the

184 spirotetramat $(2 \mathrm{x})$ treatments. Liquid treatments in both trials were applied using $2 \mathrm{~L}$ handheld

185 pump sprayers. One sprayer was calibrated to spray in a 5-8 $\mathrm{cm}$ swath for band applications and 
186 the other was calibrated to spray a mist of $\sim 30 \mathrm{~cm}$ broadcast over the entire soil/leaf surface.

187 Mechanical incorporation of treatments into the upper 5-10 cm of soil and irrigation was

188 performed as recommended (Table 1).

189 On July 15, 2014 (MP 1) and July 23, 2015 (MP 2) each microplot was planted with 20

190 seeds of the common commercial green baby lima bean cv. 'Cypress' in a circular row $36 \mathrm{~cm}$ in

191 diameter. Seeds were treated with polymer coat containing $0.05 \mathrm{~g}$ a.i. of Fludioxonil per $\mathrm{kg}$ and,

$1920.20 \mathrm{~g}$ a.i. of Metalaxyl M per kg, Lorsban, and a colorant.

193 Emergence was recorded 13 and 14 DAP for MP 1 and MP 2, respectively. Early season

194 roots from MP 1 were collected 37 DAP by removing 3 plants and rating them for root gall

195 severity. Mid-season roots were collected as described above 62 DAP in MP 1 (3 root systems),

196 and 42 DAP in MP 2 (5 root systems). At harvest, 5 root systems were collected 83 DAP (MP 1)

197 and 10 root systems were collected 82 DAP (MP 2). Severity of root galling was rated from 0 to

19810 using the following scale: $0=0-5 \%, 1=6-15 \%, 2=16-25 \%, 3=26-35 \%, 4=36-45 \%, 5=$

$19946-55 \%, 6=56-65 \%, 7=66-75 \%, 8=76-85 \%, 9=86-95 \%$ and $10=96-100 \%$ of the root

200 surface area galled (Bridge and Page 1980). Six soil samples were collected (0 to $30 \mathrm{~cm})$ with a

201 probe near the lima bean roots in each microplot at harvest and J2 were extracted from $100 \mathrm{cc}$

202 subsamples of thoroughly mixed soil via decantation and sieving and sucrose centrifugation

203 (Byrd et al. 1976, Jenkins 1964). RKN were identified morphologically and enumerated under a

204 light microscope. Initial RKN J2 populations were determined to be uniformly absent via soil

205 sampling in untreated control plots, before the addition of inoculum. RKN eggs were extracted

206 from five lima bean roots at harvest with 0.5\% NaOCl (Hussey and Barker 1973). 
Aboveground biomass was recorded for each microplot. Yields were calculated from the remaining plants in each treatment plot, as a plot average of numbers and weights $(\mathrm{g})$ of full, flat, 209 and dry lima bean pods, along with average shelled bean weight for each treatment plot.

211 Fit test, before mean comparisons. RKN populations, lima bean emergence, and yield data were

212 subjected to analysis of variance (ANOVA) and following significant results, means were 213 separated according to the Student's Protected LSD tests. In MP 1 and MP 2, lima bean 214 emergence data were arc-sine transformed, and in MP 2, the number of eggs per root fresh 215 weight $(\mathrm{g})$ and the number of $\mathrm{J} 2$ per $100 \mathrm{cc}$ soil were $\mathrm{LN}$ and $\log _{10}+1$ transformed, respectively, 216 before statistical analyses. Root ratings were subjected to Wilcoxon Rank Sums Tests for 217 comparison of nonparametric data via rankings and transformed to the midpoints of the 218 percentage ranges (Kleczewski and Flory 2010). A significance level of $\alpha=0.05$ was used in all 219 analyses. 
Table 1: Microplot (MP) and Greenhouse (GH) Trials: Chemical treatments, active ingredients, 222 rates, modes of action, application methods, and experimental setting.

\begin{tabular}{|c|c|c|c|c|c|}
\hline $\begin{array}{l}\text { Trade } \\
\text { Name }\end{array}$ & $\begin{array}{c}\text { Active } \\
\text { Ingredient }\end{array}$ & $\begin{array}{l}\text { Rate } \\
\text { (ai/ha) }\end{array}$ & Mode of Action & Application Method & $\begin{array}{c}\text { Exp. } \\
\text { Included }\end{array}$ \\
\hline $\begin{array}{l}\text { Luna } \\
\text { Privilege } \\
\text { SC }\end{array}$ & Fluopyram & $0.22 \mathrm{~L}$ & $\begin{array}{l}\text { Succinate } \\
\text { dehydrogenase } \\
\text { inhibitor (SDHI) }\end{array}$ & $\begin{array}{l}5-8 \mathrm{~cm} \text { band, below } \\
\text { the seed in-furrow }\end{array}$ & $\begin{array}{l}\text { MP 1, 2; } \\
\text { GH 1, 2 }\end{array}$ \\
\hline $\begin{array}{l}\text { Luna } \\
\text { Privilege } \\
\text { SC } \\
\rightarrow \text { Movent } \\
\text { o } 240 \text { SC }\end{array}$ & $\begin{array}{l}\text { Fluopyram, } \\
\text { Spirotetramat }\end{array}$ & $\begin{array}{l}0.22 \mathrm{~L}, \\
0.37 \mathrm{~L}\end{array}$ & $\begin{array}{l}\text { Succinate } \\
\text { dehydrogenase } \\
\text { inhibitor (SDHI), } \\
\text { Inhibitor of acetyl } \\
\text { CoA carboxylase }\end{array}$ & $\begin{array}{l}5-8 \mathrm{~cm} \text { band, below } \\
\text { the seed in-furrow } \\
\text { and a foliar broadcast } \\
\text { spray }\end{array}$ & $\begin{array}{l}\text { MP 2; } \\
\text { GH 1, } 2\end{array}$ \\
\hline $\begin{array}{l}\text { Mocap } \\
15 G\end{array}$ & Ethoprophos & $4.10 \mathrm{~kg}$ & $\begin{array}{l}\text { Acetylcholinesterase } \\
\text { inhibitor (AChE) }\end{array}$ & $\begin{array}{l}30 \mathrm{~cm} \text { band, } \\
\text { incorporated }^{\mathrm{x}}\end{array}$ & $\begin{array}{l}\text { MP 1, 2; } \\
\text { GH 1,2 }\end{array}$ \\
\hline $\begin{array}{l}\text { Movento } \\
240 \mathrm{SC} \\
(2 \mathrm{x})\end{array}$ & Spirotetramat & $\begin{array}{l}0.37 \mathrm{~L} \\
(2 \mathrm{x})\end{array}$ & $\begin{array}{l}\text { Inhibitor of acetyl } \\
\text { CoA carboxylase }\end{array}$ & $\begin{array}{l}\text { Foliar broadcast } \\
\text { sprays }\end{array}$ & $\begin{array}{l}\text { MP 2; } \\
\text { GH 1, } 2^{y}\end{array}$ \\
\hline $\begin{array}{l}\text { Nimitz } 480 \\
\text { EC }\end{array}$ & Fluensulfone & $1.64 \mathrm{~L}$ & $\begin{array}{l}\text { Nematode specific } \\
\text { serotonin pathway }\end{array}$ & $\begin{array}{l}\text { Soil broadcast spray, } \\
\text { irrigated }\end{array}$ & $\begin{array}{l}\text { MP 2; } \\
\text { GH 1, } 2\end{array}$ \\
\hline $\begin{array}{l}\text { Nimitz } 480 \\
\text { EC }\end{array}$ & Fluensulfone & $2.34 \mathrm{~L}$ & $\begin{array}{l}\text { Nematode specific } \\
\text { serotonin pathway }\end{array}$ & $\begin{array}{l}\text { Soil broadcast spray, } \\
\text { irrigated }\end{array}$ & $\begin{array}{l}\text { MP 1, 2; } \\
\text { GH 1, } 2\end{array}$ \\
\hline Vydate L & Oxamyl & $2.25 \mathrm{~L}$ & $\begin{array}{l}\text { Acetylcholinesterase } \\
\text { Inhibitor (AChE) }\end{array}$ & $\begin{array}{l}\text { Soil broadcast spray, } \\
\text { incorporated }\end{array}$ & $\begin{array}{l}\text { MP 2; } \\
\text { GH 1, } 2\end{array}$ \\
\hline $\begin{array}{l}\text { Untreated } \\
\text { Control }\end{array}$ & N/A & N/A & N/A & N/A & $\begin{array}{l}\text { MP 1, 2; } \\
\text { GH 1, }\end{array}$ \\
\hline
\end{tabular}


228 3.1. Greenhouse Experiments

229 Some replicates were lost in GH 2 due to poor emergence resulting from overwatering. 230 Loss of replication was random across treatments, with each egg concentration $\mathrm{x}$ nematicide 231 treatment achieving at least 3 replications.

232 3.1.1. Effects of Nematicides on Plant Growth and Biomass Allocation

233 In non-inoculated treatments, none of the tested nematicides had significant effects on 234 total plant biomass $\left[F_{12,35}=0.42, p=0.95(\mathrm{GH} 1) ; F_{12,23}=1.44, p=0.22(\mathrm{GH} 2)\right]$ nor percent 235 root weight of the total biomass $\left[F_{12,35}=0.52, p=0.88(\mathrm{GH} 1) ; F_{12,23}=1.55, p=0.18(\mathrm{GH} 2)\right]$ 236 in either greenhouse trial (data not shown). No evidence of phytotoxicity (i.e., chlorosis, growth 237 deformities, etc.) was observed in either trial.

238 3.1.2. Effects of Nematicides on Root Galling

239 Main effects of nematicide treatments and egg level, but not their interactions, were 240 significant for root galling in both GH trials (Table 2). Root galling in the 30,000 egg pot ${ }^{-1}$ 241 treatments was more than $264 \%$ and $144 \%$ greater than in the 6,000 egg pot $^{-1}$ rate in the GH 1 242 and GH 2 trials, respectively (data not shown). 
244 Table 2: Results of ANOVA on LN transformed Meloidogyne incognita (RKN) egg masses per 245 gram lima bean root dry weight in Greenhouse (GH) trials.

\begin{tabular}{llccccc}
\hline \multicolumn{7}{c}{ Number of RKN egg masses per $(\mathrm{g})$ dry root weight } \\
\hline & \multicolumn{5}{c}{ GH 1 } & \multicolumn{4}{c}{ GH 2 } \\
\hline Factor & $\mathrm{df}^{\mathrm{x}}$ & $F^{\mathrm{y}}$ & $P^{\mathrm{z}}$ & $\mathrm{df}$ & $F$ & $P$ \\
\hline Nematicide Treatment & 7 & 12.38 & $<0.0001$ & 7 & 5.36 & 0.0002 \\
Egg Concentration & 1 & 33.91 & $<0.0001$ & 1 & 7.63 & 0.009 \\
T x E & 7 & 0.50 & 0.833 & 7 & 2.04 & 0.073 \\
Error & 79 & & & 44 & & \\
\hline
\end{tabular}

$246 \quad{ }^{\mathrm{x}}$ Degrees of freedom.

$247{ }^{\mathrm{y}} F$-statistic.

$248 \quad{ }^{\mathrm{z}} P$-value.

In GH 1, all nematicide treatments except spirotetramat significantly reduced root galling 251 relative to the untreated control (Table 3). Ethoprophos reduced galling by nearly $77 \%$ compared 252 to the untreated control, but was not different from fluopyram, fluopyram + spirotetramat, and 253 oxamyl. Fluensulfone at both rates $\left(1.64 \mathrm{~L}\right.$ and $2.34 \mathrm{~L}$ a.i. $\left.\mathrm{ha}^{-1}\right)$ resulted in the greatest reduction 254 of root galling (Table 3). In GH 2, spirotetramat and ethoprophos did not reduce root galling 255 compared to the untreated control (Table 3). Root galling was reduced the most by both 256 fluensulfone rates (1.64L and 2.34L a.i. $\mathrm{ha}^{-1}$ ), fluopyram, and fluopyram + spirotetramat 257 treatments. No correlations between root galling and plant biomass measurements were detected. 
Table 3: Meloidogyne incognita (RKN)egg masses per gram lima bean root dry weight as 260 affected by nematicide treatment in Greenhouse $(\mathrm{GH})$ trials.

\begin{tabular}{lrr}
\hline & \multicolumn{2}{c}{ RKN egg masses per (gram) root dry weight } \\
\hline Nematicide Treatment & GH 1 & GH 2 \\
\hline Control & $148.9 \pm 38.2 \mathrm{a}^{\mathrm{z}}$ & $361.3 \pm 49.1 \mathrm{a}$ \\
Ethoprophos & $34.6 \pm 40.2 \mathrm{c}$ & $77.3 \pm 54.9 \mathrm{abc}$ \\
Fluensulfone $\left(2.34 \mathrm{~L}\right.$ a.i. $\left.\mathrm{ha}^{-1}\right)$ & $14.0 \pm 38.2 \mathrm{~d}$ & $67.6 \pm 50.9 \mathrm{~cd}$ \\
Fluensulfone $\left(1.64 \mathrm{~L}\right.$ a.i. ha $\left.^{-1}\right)$ & $6.4 \pm 38.2 \mathrm{~d}$ & $37.2 \pm 49.6 \mathrm{~d}$ \\
Fluopyram & $66.4 \pm 38.2 \mathrm{c}$ & $63.9 \pm 64.7 \mathrm{~cd}$ \\
Fluopyram + spirotetramat & $65.0 \pm 38.2 \mathrm{c}$ & $31.1 \pm 53.9 \mathrm{~cd}$ \\
Oxamyl & $134.3 \pm 38.2 \mathrm{bc}$ & $108.2 \pm 46.7 \mathrm{bc}$ \\
Spirotetramat & $183.0 \pm 38.2 \mathrm{ab}$ & $204.3 \pm 53.9 \mathrm{ab}$ \\
\hline${ }^{7}$ LS means \pm the standard error. Any means within the same column not connected by the same letter are considered \\
significantly different according to Protected LSD $(\alpha=0.05)$. Statistical analysis conducted on LN transformed data. \\
Back transformed data depicted.
\end{tabular}

\subsection{Microplot Experiments}

\subsubsection{Effects of Nematicides on Lima Bean Emergence}

In both MP experiments, nematicide treatment significantly affected lima bean

267 emergence $\left(F_{3,16}=16.27, p<0.0001\right.$ in MP $1 ; F_{7,32}=2.51, p=0.036$ in MP 2). In MP 1 , all

268 nematicide treatments significantly reduced emergence compared to the control (Table 4). The

269 greatest reduction of emergence occurred in ethoprophos and fluensulfone treatments (2.34L a.i.

$270 \mathrm{ha}^{-1}$ ) with reductions of $49 \%$ and $35 \%$ compared to the untreated control, respectively. In MP 2,

271 a reduction in emergence was only detected in spirotetramat and ethoprophos and fluensulfone

272 (2.34L a.i. ha $\left.{ }^{-1}\right)$ treatments (Table 4). 
274 Table 4: Mean emergence (\%) of lima bean seedlings as affected by nematicide treatment in

275 Microplot (MP) experiments.

\begin{tabular}{lcc}
\hline & MP 1 & MP 2 \\
\hline Nematicide Treatment & $\begin{array}{c}\text { Emergence } \\
(\%)\end{array}$ & $\begin{array}{c}\text { Emergence } \\
(\%)\end{array}$ \\
\hline Control & $94 \pm 5.05 \mathrm{a}^{\mathrm{y}}$ & $95 \pm 4.68 \mathrm{a}$ \\
Fluopyram & $73 \pm 5.05 \mathrm{~b}$ & $84 \pm 4.68 \mathrm{abc}$ \\
Ethoprophos & $48 \pm 5.05 \mathrm{c}$ & $67 \pm 4.68 \mathrm{c}$ \\
Fluensulfone (2.34L a.i. $\left.\mathrm{ha}^{-1}\right)$ & $61 \pm 5.05 \mathrm{bc}$ & $82 \pm 4.68 \mathrm{bc}$ \\
Fluensulfone (1.64L a.i. ha $\left.^{-1}\right)$ & $-\mathrm{z}$ & $83 \pm 4.68 \mathrm{ab}$ \\
Fluopyram + spirotetramat & - & $85 \pm 4.68 \mathrm{ab}$ \\
Spirotetramat (2x) & - & $79 \pm 4.68 \mathrm{bc}$ \\
Oxamyl & - & $91 \pm 4.68 \mathrm{ab}$ \\
\hline
\end{tabular}

${ }^{\mathrm{y}}$ LS Means \pm standard error. Any means within the same column not connected by the same letter are considered significantly different according to Protected LSD $(\alpha=0.05)$. Statistical analysis conducted on ArcSin transformed data. Back transformed data depicted.

${ }^{\mathrm{z}}$ Nematicides were not treatments in MP 1, only MP 2.

\subsubsection{RKN Densities}

RKN J2 and eggs were not collected in MP 1. In MP 2, nematicide treatment affected

RKN J2 densities per $100 \mathrm{cc}$ soil $\left(F_{7,32}=25.32, p<0.0001\right)$. Only spirotetramat treatments did not significantly reduce RKN J2 abundance relative to the untreated control (Table 5). Ethoprophos reduced $\mathrm{J} 2$ abundance by over $99 \%$ compared to the untreated control and nearly $94 \%$ compared to the closest treatment, fluopyram (Table 5). J2 abundance was negatively correlated with lima bean pod yield (Spearman's $\rho(38)=-0.47, p=0.0026)$. associated with J2 abundance [Spearman's $\rho(38)=-0.41, p=0.0083$ ]. 
Table 5: Mean densities of Meloidogyne incognita (RKN) second-stage juveniles (J2) per 100cc soil and eggs per gram lima bean root fresh weight, as affected by nematicide treatment, at

295 harvest in the Microplot (MP) 2 experiment.

\begin{tabular}{lrc}
\hline Nematicide Treatment & $\begin{array}{c}\text { RKN J2 } \\
\text { (\#per 100cc soil) }\end{array}$ & $\begin{array}{c}\text { RKN Eggs } \\
\text { (\# per gram root weight) }\end{array}$ \\
\hline Control & $16,669 \pm 1,542 \mathrm{a}^{\mathrm{z}}$ & $39.9 \pm 17.2 \mathrm{cde}$ \\
Fluopyram & $1,943 \pm 1,542 \mathrm{~d}$ & $81.4 \pm 17.2 \mathrm{ab}$ \\
Ethoprophos & $121 \pm 1,542 \mathrm{e}$ & $116.9 \pm 17.2 \mathrm{a}$ \\
Fluensulfone (2.34L a.i. ha ${ }^{-1}$ ) & $2,603 \pm 1,542 \mathrm{~d}$ & $44.7 \pm 17.2 \mathrm{bc}$ \\
Fluensulfone (1.64L a.i. ha $\left.{ }^{-1}\right)$ & $5,995 \pm 1,542 \mathrm{bc}$ & $38.1 \pm 17.2 \mathrm{~cd}$ \\
Fluopyram + spirotetramat & $2,165 \pm 1,542 \mathrm{~d}$ & $37.0 \pm 17.2 \mathrm{~cd}$ \\
Spirotetramat (2x) & $11,780 \pm 1,542 \mathrm{ab}$ & $20.9 \pm 17.2 \mathrm{e}$ \\
Oxamyl & $3,522 \pm 1,542 \mathrm{~cd}$ & $23.1 \pm 17.2 \mathrm{de}$ \\
\hline
\end{tabular}

296

297

298

299

300

301

302

303

304

305

306

307

308

309

310

311

${ }^{2}$ LS means \pm standard error. Any means within the same column not connected by the same letter are considered significantly different according to Protected LSD $(\alpha=0.05)$. Statistical analysis conducted on $\log _{10}$ transformed data. Back transformed data depicted.

\subsubsection{Effects of Nematicides on Root Galling}

In both MP experiments, nematicide treatments had significant effects on root galling at harvest according to Kruskal-Wallis tests (Chi-square $=16.39, p=0.0009$ in MP 1; Chi-square $=$ 34.33, $p=<0.0001$ in MP 2). In MP 1, all nematicide treatments except fluopyram reduced root galling relative to the untreated control (Fig. 1). However, fluensulfone (2.34L a.i. ha $\left.{ }^{-1}\right)$ reduced root galling to the greatest degree, $74 \%$ compared to the untreated control (Figure 1). In MP 2, all nematicide treatments except spirotetramat significantly reduced root galling compared to the untreated control, with ethoprophos reducing root galling the most with an $81 \%$ reduction

(Figure 1). In both experiments, root galling at harvest was negatively associated with lima bean pod yield, [Spearman's $\rho(18)=-0.68, p=0.001$ (MP 1); Spearman's $\rho(37)=-0.41, p=0.0092$
(MP 2)]. 


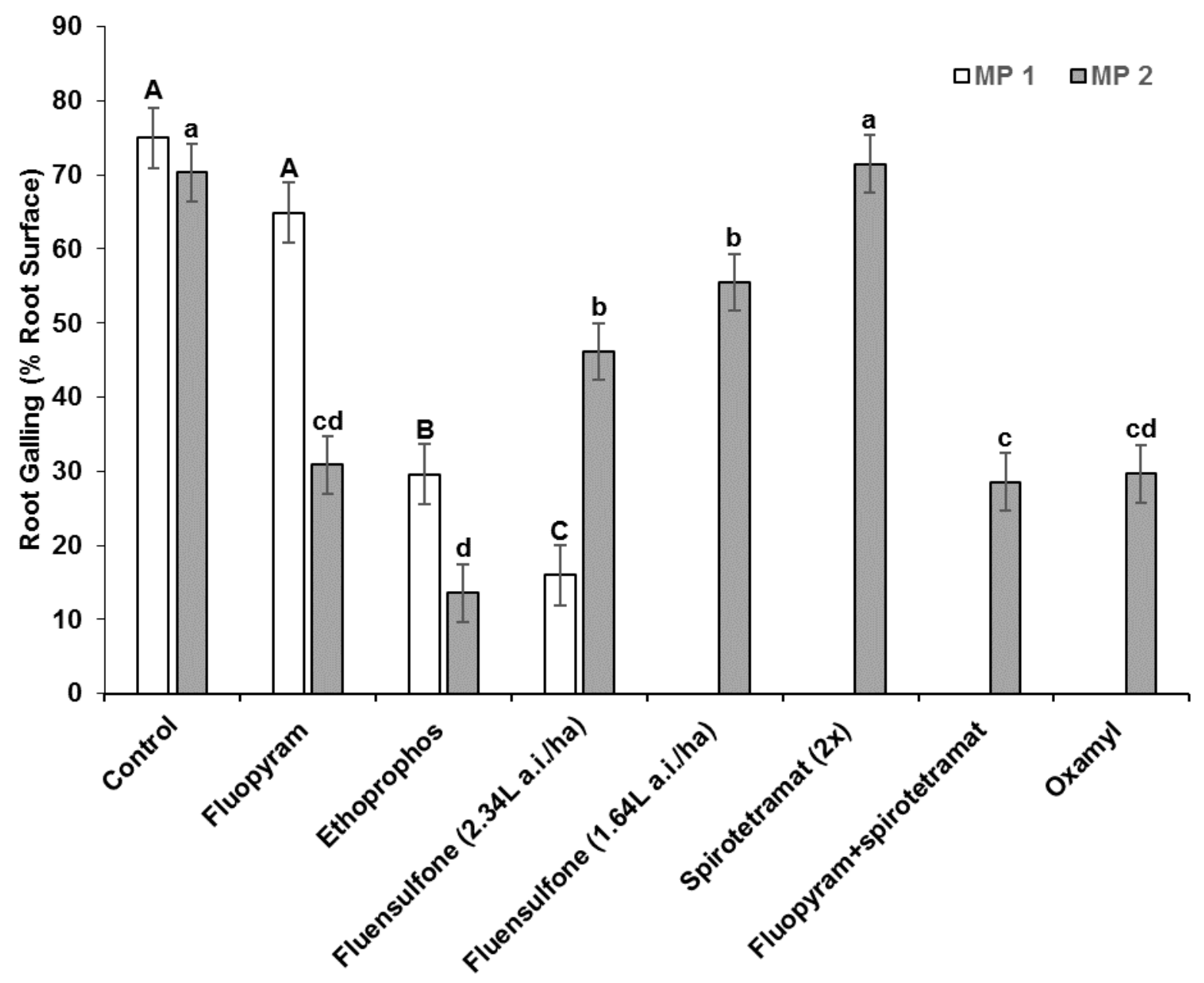

Fig. 1. Root gall ratings from Meloidogyne incognita on lima bean as affected by nematicide treatments at harvest for Microplot (MP) experiments. Bar values represent Means \pm standard error of five replicates. Treatments within the same experiment, connected by the same letter (capital letters for MP 1 and lowercase letters for MP 2) are not significantly different according to separate Wilcoxon Rank Sums Tests $(\alpha=0.05)$. Root galls were rated on a 0-10 scale, comparing the root surface area with galls to the total root surface area: $0=0-5 \%, 1=6-15 \%, 2=16-25 \%, 3=$ $26-35 \%, 4=36-45 \%, 5=46-55 \%, 6=56-65 \%, 7=66-75 \%, 8=76-85 \%, 9=86-95 \%$ and $10=96-100 \%$ of the root surface area galled. 


\subsubsection{Effects of Nematicides on Lima Bean Yields}

In both MP experiments, lima bean yields were significantly increased by nematicide treatment $\left[F_{3,16}=5.92, p=0.007(\mathrm{MP} 1) ; F_{7,31}=6.87, p<0.0001\right.$ (MP 2)]. In MP 1, ethoprophos and fluensulfone $\left(2.34 \mathrm{~L}\right.$ a.i. $\mathrm{ha}^{-1}$ ) increased yields by over $191 \%$ and $220 \%$ compared to the untreated control, respectively (Table 6). Fluopyram did not significantly increase yields. In MP 2, all treatments except spirotetramat increased yields compared to the untreated control (Table 6). Both fluensulfone rates (1.64L and $2.34 \mathrm{~L}$ a.i. ha ${ }^{-1}$ ), oxamyl, and ethoprophos treatments resulted in the greatest yields.

Table 6: Mean lima bean pod weights(grams) per plot as affected by nematicide treatments in Microplot (MP) experiments.

\begin{tabular}{lcc}
\hline & MP 1 & MP 2 \\
\hline Nematicide Treatment & Pod Weight $(\mathrm{g})$ & Pod Weight $(\mathrm{g})$ \\
\hline Control & $256 \pm 60.7 \mathrm{c}^{\mathrm{y}}$ & $30 \pm 20.9 \mathrm{~d}$ \\
Fluopyram & $342 \pm 60.7 \mathrm{bc}$ & $99 \pm 20.9 \mathrm{bc}$ \\
Ethoprophos & $488 \pm 60.7 \mathrm{ab}$ & $128 \pm 20.9 \mathrm{ab}$ \\
Fluensulfone (2.34L a.i. $\left.\mathrm{ha}^{-1}\right)$ & $562 \pm 60.7 \mathrm{a}$ & $127 \pm 20.9 \mathrm{ab}$ \\
Fluensulfone (1.64L a.i.ha $\left.{ }^{-1}\right)$ & $-{ }^{\mathrm{z}}$ & $130 \pm 23.7 \mathrm{ab}$ \\
Fluopyram + spirotetramat & - & $94 \pm 20.9 \mathrm{bc}$ \\
Spirotetramat (2x) & - & $50 \pm 20.9 \mathrm{~cd}$ \\
Oxamyl & - & $196 \pm 20.9 \mathrm{a}$ \\
\hline
\end{tabular}

${ }^{\mathrm{y}} \mathrm{LS}$ means \pm standard error of five replicates. Any means within the same column not connected by the same letter are considered significantly different according to Protected LSD $(\alpha=0.05)$. Analysis performed on square root transformed data. Back transformed data shown.

${ }^{\mathrm{z}}$ Nematicides were not treatments in MP 1, only MP 2.

\section{Discussion}

In this study, we identified several new nematicide chemicals, currently unlabeled on lima beans, that suppressed RKN populations and promoted lima bean growth. To our knowledge, this is the first time these products have been assessed in lima bean. Data generated here may be useful in developing label additions to include these newer products on lima beans. 
342 application resulted in the greatest reduction of RKN in the greenhouse, while ethoprophos did

343 so in the microplots. Spirotetramat did not appear to have efficacy against RKN in lima beans in

344 either experimental setting. The interaction between egg level and nematicide treatment in the 345 greenhouse was not significant, suggesting that the nematicides suppressed RKN at both low

346 (6,000 eggs/pot) and high (30,000 eggs/pot) population levels, without breakdowns in efficacy.

347 No phytotoxic or beneficial effects on plant growth were found following nematicide application

348 in the greenhouse in nematode-free controls. However, fluensulfone and ethoprophos reduced

349 seedling emergence significantly compared to the untreated controls in the microplot trials.

Results from the greenhouse and microplot trials suggest spirotetramat has limited

351 efficacy against RKN in lima bean. Spirotetramat did not reduce root galling compared to the

352 untreated control when applied 19 (GH 1), 16 (GH 2), and 20 DAP (MP 2). The timing of foliar

353 spirotetramat application is critical to its success as a nematicide. In a study on tomato by Vang

354 et al. (2016), application of spirotetramat prior to RKN inoculation and 3 weeks post RKN

355 inoculation did not consistently reduce the number of RKN egg masses, similar to our findings;

356 conversely, application to foliage 1 or 2 weeks post inoculation did suppress egg mass

357 production. In order to be effective, spirotetramat must be ingested by the target organism, and

358 thus RKN egg mass production will not be reduced in the first population cycle, helping to

359 explain our findings in the single-generation time greenhouse trials (Nauen et al. 2008, Vang et

360 al. 2016). Fecundity, which was measured via egg extraction and enumeration, is a more

361 valuable metric than the number of egg masses or extent of galling for determining the efficacy

362 of spirotetramat (Vang et al. 2016). RKN egg density, therefore fecundity of RKN females, in

363 lima bean roots in MP 2 was not reduced significantly following spirotetramat application. 
364 Smiley et al. (2011) called for the examination of spirotetramat as a companion treatment in

365 combination with an early-season nematicide treatment for season-long nematode control and 366 protection of crop plants, since spirotetramat cannot be applied until adequate leaf surface has 367 emerged. In our study, fluopyram pre-plant plus spirotetramat at 19 (GH 1), 16 (GH 2) and 20 368 DAP (MP 2) did not improve RKN control when compared to fluopyram alone, except in one 369 measure in MP 2, where a reduction in egg density in the lima bean roots was recorded. This 370 suggests there was a decrease in fecundity due to spirotetramat, similar to Vang et al. (2016). In a 371 study by McKenry et al. in 2011, nematode control by spirotetramat was enhanced by waiting 372 nine days before resumption of irrigation. No break in irrigation was performed in our studies, 373 perhaps contributing to the lack of efficacy of spirotetramat.

374 Fluopyram performed well in all trials, except in MP 1, where root galling was similar to 375 the untreated control. Fluopyram application can result in a characteristic "halo effect" or 376 damage to the cotyledons of emerging seedlings (Kendal et al. 2016). We recorded a $22 \%$ 377 reduction in emergence due to fluopyram application in MP 1, similar to the findings of Kandel 378 et al. (2016), who observed a reduction in soybean stand following fluopyram seed treatment in 379 their study. In MP 2, fluopyram outperformed fluensulfone in reducing RKN galling and J2 380 populations in the soil, and was only outperformed in reducing RKN galling by fluensulfone in 381 one of the greenhouse trials (GH 1). Overall, fluopyram performed well in our study warranting 382 further research on potential registration for RKN control in lima beans as a seed treatment or in383 furrow application. It is already labeled as a seed treatment nematicide in soybeans (ILeVOß) 384 and as an in-furrow application, or chemigated through drip, trickle or subsurface irrigation 385 systems in cotton and peanuts (Velum Total $®)$. 
Fluensulfone has been shown to suppress RKN populations in multiple vegetable

cropping systems and is currently registered on cucumbers, melons, squash, tomatoes, okra, peppers, and eggplant as Nimitz ${ }^{\circledR}$ (Morris et al. 2016, Oka et al. 2011, Kearn et al. 2014, Adama Ag Solutions, Raleigh, N.C.). Fluensulfone significantly reduced RKN galling in GH 1 and MP 1 more than any other nematicide tested. Our greenhouse results were similar to those obtained by Oka et al. (2011) where fluensulfone outperformed oxamyl. Fluensulfone can be applied in a broadcast/band spray that is followed by mechanical incorporation and irrigation (Oka et al. 2009; Nimitz Label). One limitation of fluensulfone is the 7-day pre-plant interval for seedling safety (Nimitz Label). We observed phytotoxicity following fluensulfone application in MP 1 and MP 2, similar to Morris et al. (2016) and Oka et al. (2009). Lima bean seedling emergence was reduced when the 7-day pre-plant interval was not followed in our trials. In MP 2, both fluensulfone rates (1.64 and 2.34L a.i./ha) reduced root gall ratings similarly, but were outperformed by oxamyl, fluopyram, and ethoprophos treatments. Better control of RKN was recorded in GH 1 and GH 2 following the 7-day waiting period. Examination of the more economical band-application method of fluensulfone in lima bean is warranted as well as studying the duration of control.

In addition to the newly registered nematicides, ethoprophos (an organophosphate) and oxamyl (a carbamate) were also studied. Ethoprophos was introduced in the 1960s and the granular formulation has long been labeled for use in lima bean as Mocap ${ }^{\circledR}$ (Chitwood 2001, Amvac Chemical Corp. Los Angeles, CA). One concern is the phytotoxicity associated with the chemical, which in our microplot trials reduced lima bean seedling emergence almost $40 \%$ when compared to the untreated controls. This is similar to research by Sinclair et al. (1992) who found that even when applied correctly, ethoprophos can be phytotoxic to carrot seedlings. 
Ethoprophos performed well in our trials, with among the best RKN control in all but the GH 2 trial. In MP 2, ethoprophos had the lowest root gall ratings of all nematicides tested and the fewest number of $\mathrm{J} 2$ in the soil, a reduction of nearly $94 \%$ compared to the next lowest number of $\mathrm{J} 2$ following fluopyram application. The low number of $\mathrm{J} 2$ in the soil could be somewhat attributed to the limited root surface area resulting from poor emergence following ethoprophos application. However, the results suggest that lima bean growers' long-used tool is still highly effective at controlling RKN using the current label rates and application methods.

In summary, ethoprophos continues to be an effective chemical for controlling RKN in lima beans, although additional research on phytotoxicity should be considered. Fluopyram and fluensulfone show promise as forthcoming tools. We are the first to demonstrate that fluopyram and fluensulfone can reduce RKN galling on lima bean and provide support that a seed treatment application of fluopyram in lima bean should be evaluated. If research supports the efficacy of this product and a label can be obtained, it would benefit lima bean production in the midAtlantic, where nematodes are becoming a greater threat to production (PMSP 2003). Further research into the yield effects of the nematicides are needed, along with determination of an economic threshold for RKN in lima bean cropping systems to ascertain when nematicide application is warranted.

\section{Acknowledgements}

I would like to thank everyone who lent a hand on the research projects, including assistance from Andy Kness, Heather Baker, and University of Delaware greenhouse and farm staff. This work was funded by the National Institute of Food and Agriculture, Specialty Crop Research Initiative Grant Number 2012-51181-19776. J.J. conducted and designed experiments, analyzed data, and composed the manuscript. N.K. designed experiments, assisted with data 
analysis, and assisted with manuscript composition. G.J. assisted with experimental design and contributed suggestions and edits vital to completion of the experiments and manuscript. All other authors contributed edits and suggestions vital to the project and manuscript. Mention of trade names or commercial products in this publication is solely for the purpose of providing specific information and does not imply recommendation or endorsement by the U.S.

Department of Agriculture. USDA is an equal opportunity provider and employer.

\section{REFERENCES}

Abdel-Rahman, F.H., Clark, S., Saleh, M.A., 2008. Natural organic compounds as alternative to methyl bromide for nematodes control. J. Environ. Sci. Health., Part B.43, 680-685. doi:10.1080/03601230802388751

AMVAC Chemical Corporation, 2012. Mocap ${ }^{\circledR} 15 \%$ granular nematicide-insecticide. Pesticide Product Label. U.S. Environmental Protection Agency, Washington D.C.

Aspelin, A.L., Grube, A.H., 1999. Pesticides industry sales and usage- 1996 and 1997 market estimates: U.S. Environmental Protection Agency, Pesticide Industry and Sales Usage Report 733-R-99-001, p. 39.

Barker K.R., 1998. Introduction and synopsis of advancements in nematology, in: Barker, K.R., Pederson, G.A., Windham, G.L. (Eds.), Plant and Nematode Interactions. Am. Soc. Agron., Crop Sci. Soc. of Am., Soil Sci. Soc. of Am., Madison, WI, pp 1-20.

Bayer CropScience, 2011. Movento®. Pesticide Product Label. U.S. Environmental Protection Agency, Washington D.C.

Bayer CropScience, 2015. Velum ${ }^{\circledR}$ Total. Pesticide Product Label. U.S. Environmental Protection Agency, Washington D.C.

Bridge, J., Page, S.L.J., 1980. Estimation of root-knot nematode infestation levels on roots using a rating chart. Trop. Pest Manage. 26, 296-298.

Byrd, D.W., Barker, K.R., Ferris, H., Nusbaum, C.J., Griffin, W.E., Small, R.H., Stone, C.A., 1976. Two semi-automatic elutriators for extracting nematodes and certain fungi from the soil. J.Nematol. 8, 206-212.

Chitwood, D.J., 2003. Nematicides, in Plimmer, J.R. (Ed.),Encyclopedia of Agrochemicals, Volume 3. John Wiley \&Sons. New York, pp 1104-1115. 
477

Delaware Agricultural Statistics Bulletin and Resource Directory (2013-2014). 2014. National Agricultural Statistics Service (NASS) and Delaware Department of Agriculture (DDA). Delaware Department of Agriculture, Dover, DE.

Dickson, D.W., Struble, F.B. 1965. A sieving-staining technique for extraction of egg masses of Meloidogyne incognita from soil. Phytopathology 55, 497 (Abstr.).

DuPont Crop Protection, 2009. Vydate L® Insecticide/Nematicide. Pesticide Product Label. U.S. Environmental Protection Agency, Washington D.C.

Environmental Protection Agency (EPA), 2008. Fenimaphos: Amendment to use deletion and product cancellation order. Fed. Regist. 73 (238), 75097-75099.

Environmental Protection Agency (EPA), 2009. Carbofuran; Product cancellation order. Fed. Regist. 74 (51), 11551-11513.

Environmental Protection Agency (EPA), 2012. Aldicarb; Cancellation order for amendments to terminate uses. Fed. Regist. 77 (90), 27226-27227.

Everts, K.L., Sardanelli, S., Kratochvil, R.J., Armentrout, D.K., Gallagher, L.E., 2006. Root-knot and root-lesion nematode suppression by cover crops, poultry litter, and poultry litter compost. Plant Dis. 90 (4), 487-492. doi:10.1094/PD-90-0487

Faske, T.R., Hurd, K., 2015. Sensitivity of Meloidogyne incognita and Rotylenchulusreniformis to fluopyram. J.Nematol. 47 (4), 316-321.

Giannakou, I.O., Sidiropoulos, A., Prophetou-Athanasiadou, D., 2002. Chemical alternatives to methyl bromide for the control of root-knot nematodes in greenhouses. Pest Manage. Sci. 58 (3), 290-296. doi:10.1002/ps.453

Gupta, R.C., 2011. Introduction, in: Gupta, R.C. (Ed.), Toxicology of Organophosphate and Carbamate Compounds. Elsevier Academic Press, Burlington, MA, pp. 3-4.

Holden-Dye, L.J., Kearn, J., Crisford, A., Ludlow, E., Urwin, P.E., Lilley, C.J. O’Connor, V., 2015. The nematicidal mode of action of fluensulfone. J. Nematol. 47 (3), 244 (Abstr.).

Hussey, R.S., Barker, K.R., 1973. A comparison of methods of collecting inoculaofMeloidogyne spp., including a new technique. Plant Dis. Rep. 57, 1025-1028.

Insecticide Resistance Action Committee (IRAC), International Mode of Action Working Group, 2015. IRAC Mode of action classification scheme. Version 8.0.

Jenkins, W.R., 1964. A rapid centrifugal-flotation technique for separating nematodes from soil. Plant Dis. Rep. 48, 692. 
Johnson, A.W., Feldmesser, J., 1987. Nematicides- a historical review, in: Veech, A., Dickson, D.W. (Eds.), Vistas on Nematology: A Commemoration of the Twenty-Fifth Anniversary of the Society of Nematologists. Soc. of Nematol., Hyattsville, MD, pp. 448-454.

Jones, J.T., Haegeman, A., Danchin, E.G.J., Gaur, H.S., Helder, J., Jones, M.G.K., Kikuchi, T., Manzanilla-López, R., Palomares-Rius, J.E., Wesemael, W.M.L., Perry, R.N., 2013. Top 10 plant-parasitic nematodes in molecular plant pathology. Mol. Plant Pathol. 14 (9), 946-961. doi: $10.1111 / \mathrm{mpp} .12057$

Kandel, Y.R., Wise, K.A., Bradley, C.A., Tenuta, A.U., Mueller, D.S., 2016. Effect of planting date, seed treatment, and cultivar on plant population, sudden death syndrome, and yield of soybean. Plant Dis. 100, 1735-1743. doi:10.1094/PDIS-02-16-0146-RE

Karssen, G., Wesemael, W., Moens, M., 2013. Root-knot nematodes, in: Perry, R.N., Moens, M. (Eds.), Plant Nematology, 2nd Edition. CAB International. Wallingford, UK, pp. 73-108.

Kayani, M.Z., Mukhtar, T., Hussain, M.A., 2017. Effects of southern root knot nematode population densities and plant age on growth and yield parameters of cucumber. Crop Prot. 92, 207-212. doi:http://dx.doi.org/10.1016/j.cropro.2016.09.007

Kearn, J., Ludlow, E., Dillon, J., O’Connor, V., Holden-Dye, L., 2014. Fluensulfone is a nematicide with a mode of action distinct from anticholinesterases and macrocyclic lactones. Pestic. Biochem. Physiol. 109, 44-57. doi:10.1016/j.pestbp.2014.01.004

Kleczewski, N.M., Flory, S.L., 2010. Leaf blight disease on the invasive grass Microstegiumvimineum caused by a Bipolaris sp. Plant Dis. 94, 807-811.

Kofoid, C.A., White, W.A., 1919. A new nematode infection of man. J. Am. Med. Assoc. 72, 567-569.

MakhteshimAgan of North America, Inc. (d/b/a ADAMA), 2015. NIMITZ® 480 EC. Pesticide Product Label. U.S. Environmental Protection Agency, Washington D.C.

McCarter, J. P., 2008. Nematology: terra incognita no more. Nat.Biotechnol. 26 (8), 882-884. doi:10.1038/nbt0808-882

McKenry, M., Buzo, T., Kaku, S., 2010. Performance of spirotetramat foliar on Pratylenchusvulnus infected Juglans spp. J. Nematol. 42, 257 (Abstr.).

McKenry, M., Kaku, S., Buzo, T., 2009. Evaluation of Movento® (spirotetramat) for efficacy against nematodes infesting perennial crops. J. Nematol. 41, 355 (Abstr).

McKenry, M., Kaku, S., Buzo, T., 2011. Timing of post treatment irrigation impacts the nematicidal value of spirotetramat. J.Nematol. 43, 262-263 (Abstr). 
Moens, M., Perry, R.N., Starr, J.L., 2009Meloidogyne species- a diverse group of novel and important plant parasites, in: Perry, R.N., Moens, M., Starr, J.L. (Eds.), Root-knot Nematodes. CABI North American Office. Cambridge, MA,pp. 1-13.

Morris, K.A., Langston, D.B., Davis, R.F., Noe, J.P., Dickson, D.W., Timper, P., 2016. Efficacy of various application methods of fluensulfone for managing root-knot nematodes in vegetables. J.Nematol. 48 (2), 65-71.

Morris, K.A., Langston, D.B., Dickson, D.W., Davis, R.F., Timper, P., 2015. Efficacy of fluensulfone in a tomato-cucumber double cropping system. J.Nematol. 47 (4), 310-315.

Nauen, R., Reckmann, U., Thomzik, J., Thielert, W., 2008. Biological profile of spirotetramat (Movento $($ ) - a new two-way systemic (ambimobile) insecticide against sucking pest species. Bayer CropSci. J. 61, 245-278.

Nyczepir, A.P., Thomas, S.H., 2009. Current and future management strategies in intensive crop production systems, in: Perry, R.N., Moens, M., Starr, J.L. (Eds.), Root-knot Nematodes. CABI North American Office. Cambridge, MA, pp. 412-435.

Perry, R. N., Wright, D. J. Chitwood, D.J. 2013. Reproduction, physiology and biochemistry, in: Perry, R.N., Moens, M. (Eds.), Plant Nematology, 2nd Edition. CAB International. Wallingford, UK, pp. 219-245.

Pest Management Strategic Plan (PMSP) 2003. Lima beans in Delaware, New Jersey, and Maryland Eastern Shore. https://ipmdata.ipmcenters.org/documents/pmsps/MidAtlLima Bean.pdf

Oka, Y., Shuker, S., Tkachi, N., 2009. Nematicidal efficacy of MCW-2, a new nematicide of the fluoroalkenyl group, against the root-knot nematode Meloidogynejavanica. Pest Manage. Sci. 65 (10), 1082-1089. doi:10.1002/ps.1796

Oka, Y., Shuker, S., Tkachi, N., 2011. Systemic nematicidal activity of fluensulfone against the root-knot nematode Meloidogyne incognita on pepper. Pest Manage. Sci. 68 (2), 268-275. doi:10.1002/ps.2256

Sinclair, P.J., Neeson, R.J., Williams, P.A., 1992. Phytotoxicity of some organophosphate insecticides to onions and carrots during germination and emergence. Plant Prot. Q. 7 (1), 23-25.

Smiley, R.W., Marshall, J.M., Yan, G.P., 2011. Effect of foliarly applied spirotetramat on reproduction of Heteroderaavenae on wheat roots. Plant Dis. 95, 983-989. doi:10.1094/PDIS-01-11-0017

Synthesis report of the methyl bromide interim scientific assessment and methyl bromide interim technology and economic assessment. 1992, in: Montreal Protocol Assessment Supplement, United Nations Environmental Program (UNEP), Nairobi, Kenya. 
559 United States Department of Agriculture (USDA) and Natural Resource Conservation Service $560 \quad$ (NRCS). 2010. Web Soil Survey. USDA, Washington D.C.

561 Vang, L.E., Opperman, C.H., Schwarz, M.R., Davis, E.L., 2016. Spirotetramat causes an arrest 562 of nematode juvenile development. Nematology 18: 121-131. doi:10.1163/15685411$563 \quad 00002948$

564 Wallace, H.R., 1968. The Dynamics of Nematode Movement. Annu. Rev. Phytopathol. 6, 91565 114. doi:10.1146/annurev.py.06.090168.000515

566 